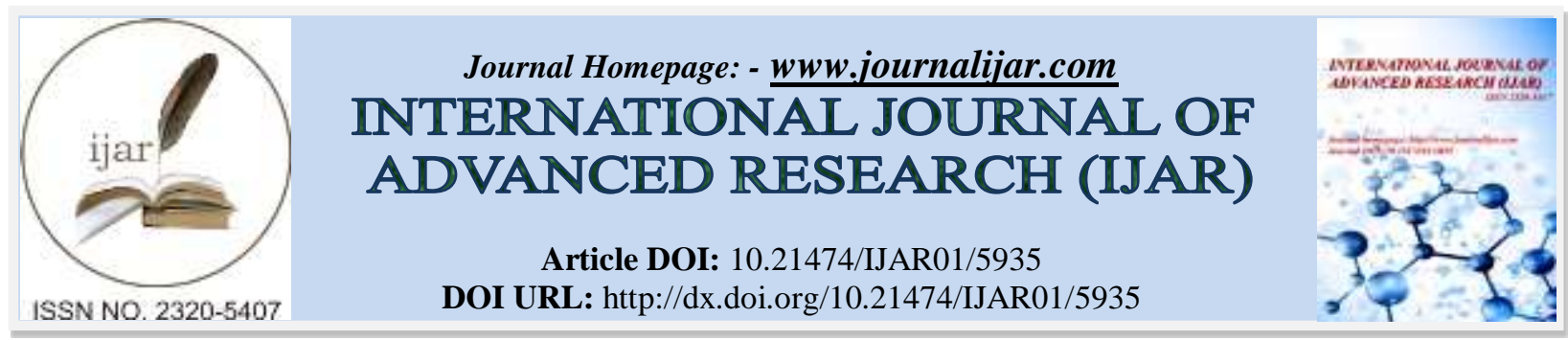

RESEARCH ARTICLE

\title{
ROLE OF LOGISTICS IN E-COMMERCE.
}

Chvaralakshmi And N.Srivani.

Assistant professor, Department of mba andhra loyola college.

\section{Manuscript Info}

Manuscript History

Received: 01 October 2017

Final Accepted: 03 November 2017

Published: December 2017

\section{Key words:-}

Ecommerce,Logistics,Warehousing, Inventory Management.

\begin{abstract}
Over the past few years, the growth of both tech hardware and the internet has had a direct correlation with eCommerce. Just as the internet has grown into the desired medium for marketing, advertising, and purchasing of products, goods, and services; eCommerce has grown to rival traditional shopping in many ways.Logistics has come a long way in the business world. There was a time when the retailers used to directly source goods from suppliers and manufacturers. Today, there are eCommerce fulfillment distribution centers for distributing the products. Logistics includes many aspects like warehousing, inventory management, billing, packaging, labelling, shipping, cash on delivery, payment, product return \& exchange, and much more. To streamline the process, the logistics firms need specialist enterprise mobility softwares which take care of most of the issues like tracking, management of stock levels, locations, packaging and fulfillment. Logistics firms also require know-how of the business \& transport regulations of the country in which they are supplying the goods. For availing logistics services, the online merchants choose reputed courier companies or specialist third party logistics providers. Some established e-tailers also create their own logistics companies as they can ensure speed and accuracy, and also save costs at the same time. Whatever method they may choose, it has to be an efficient delivery model.
\end{abstract}

Copy Right, IJAR, 2017,. All rights reserved.

\section{Introduction:-}

E-commerce is a transaction of buying or selling online. Electronic commerce draws on technologies such as mobile commerce, electronic funds transfer, supply chain management, Internet marketing, online transaction processing, electronic data interchange (EDI), inventory management systems, and automated data collectionsystems. Modern electronic commerce typically uses the World Wide Web for at least one part of the transaction's life cycle although it may also use other technologies such as e-mail. Typical e-commerce transactions include the purchase of online books (such as Amazon) and music purchases (music download in the form of digital distribution such as iTunes Store), and to a less extent, customized/personalized online liquor store inventory services.

E-commerce businesses may employ some or all of the followings:

1. Online shopping web sites for retail sales direct to consumers 
2. Providing or participating in online marketplaces, which process third-party business-to-consumer or consumerto-consumer sales

3. Business-to-business buying and selling;

4. Gathering and using demographic data through web contacts and social media

5. Business-to-business (B2B) electronic data interchange

6. Marketing to prospective and established customers by e-mail or fax (for example, with newsletters)

7. Engaging in pretail for launching new products and services

8. Online financial exchanges for currency exchanges or trading purposes.

\section{Logistics:-}

Logistics is generally the detailed organization and implementation of a complex operation. In a general business sense, logistics is the management of the flow of things between the point of origin and the point of consumption in order to meet requirements of customers or corporations. The resources managed in logistics can include physical items such as food, materials, animals, equipment, and liquids; as well as abstract items, such as time and information. The logistics of physical items usually involves the integration of information flow, material handling, production, packaging, inventory, transportation, warehousing, and often security.

In military science, logistics is concerned with maintaining army supply lines while disrupting those of the enemy, since an armed force without resources and transportation is defenseless. Military logistics was already practiced in the ancient world and as modern military have a significant need for logistics solutions, advanced implementations have been developed. In military logistics, logistics officers manage how and when to move resources to the places they are needed.

Logistics management is the part of supply chain,managementthat plans, implements, and controls the efficient, effective forward, and reverse flow and storage of goods, services, and related information between the point of origin and the point of consumption in order to meet customer's requirements. The complexity of logistics can be modeled, analyzed, visualized, and optimized by dedicated simulation software. The minimization of the use of resources is a common motivation in all logistics fields. A professional working in the field of logistics management is called a logistician.

\section{Importance of logistics in eCommerce:-}

Shopping in ecommerce every time it's normalizing more and more, reaching to be one of the shopping methods most commons in our country.

Logistics is a key point if you want your online shop to work, and for this reason we are going to tell you which is its role in the world on electronic commerce.

There are five ecommerce foundations:

1. Infrastructure. It's essential that the company, even if it's more or less big, has a good infrastructure. Is has to be able to solve the company needs fast and effective.

2. Marketing. Companies need to mix marketing offline and online actions for having a bigger impact. Marketing is necessary for getting visits of the ones that could be future buyers.

3. Payment methods. There has to be the most number of payment methods or at least have some, because they provide solutions to the users' needs.

4. Safety. For getting loyalty, clients must feel safe. An ecommerce has to generate confidence and be able to give responses. You have to be transparent with your clients and try to solve their questions.

5. Logistics. The pillar of the ecommerce. If the logistics of an ecommerce doesn't work, the company won't be profitable and the clients won't be satisfied. Keeping a good logistics will ensure you that deliveries are on time and returns or changes are controlled.

Inside logistics, there are three essential parts that you have to consider:

Logistics information systems. You have to provide logistic technologies able to follow the company's rhythm, technologies that can connect the online job with the real shop. Just if you fulfil this point, you could talk about a real ecommerce that has a satisfying shopping experience. 


\section{Storage:-}

There are some aspects you have to consider, from the order preparation, packaging, the labelling service, etc. All this steps have to be as agile as possible for the whole logistics process flows and be effective.

Distribution. Ones we have all the products ready, there's a last step, distribution. This is maybe one of the most important points, because is the one where time matters. It's important to be flexible and be able to adapt to clients, because everyone has its own needs and this is why is essential to fulfil the established times.

\section{Order Now:-}

It is not uncommon for many of us to click this button on our screens while purchasing products online. It is so simple for us, as consumers, to order for products and then get the advantage of products being delivered right at our doorsteps. Hardly do we ever ponder on the hard work and diligence that is put in behind the 'camera' which makes this possible. Just in case the delivery is not up to the mark, we say, "Oh! We will not bother to order from this website again. The delivery should be more efficient and timely." Easily said but not done. It takes a lot of effort on the part of the online retailers to find reliable logistics partners who can provide a smooth and efficient delivery of products to their customers.

eCommerce has seen an unprecedented growth and this trend is likely to boom in the coming years with the advent of mobile commerce. Consumers today are purchasing nearly everything online, from antiques to furnishings and grocery to electronics. The increasing access to internet \& broadband, availability of Smartphones, easing of norms for business ventures, the push of the present government under Narendra Modi for Digital India, recent move of SEBI to ease listing norms, raise capital and create a dedicated platform for startups to list on stock exchanges in India, are some of the stimulating factors which are spearheading the growth of a new breed of online entrepreneurs in India. Even established retailers are augmenting traditional brick-and-mortar store sales with eCommerce divisions. Having said this, it is no brainer that logistics will increasingly play a crucial role in the success of any eCommerce venture.

Logistics has come a long way in India. There was a time when the retailers used to directly source goods from suppliers and manufacturers. Today, there are eCommerce fulfillment distribution centers for distributing the products. Logistics includes many aspects like warehousing, inventory management, billing, packaging, labelling, shipping, cash on delivery, payment, product return \& exchange, and much more. To streamline the process , the logistics firms need specialist enterprise mobility softwares which take care of most of the issues like tracking, management of stock levels, locations, packaging and fulfillment. Logistics firms also require know-how of the business \& transport regulations of the country in which they are supplying the goods. For availing logistics services, the online merchants choose reputed courier companies or specialist third party logistics providers. Some established e-tailers also create their own logistics companies as they can ensure speed and accuracy, and also save costs at the same time. Whatever method they may choose, it has to be an efficient delivery model.

The eCommerce players also need to establish a system for reverse logistics which comes into play when the customer requests for return of a product because it is damaged or they wish to exchange the product for its size, colour and other reasons thereof. The online ventures have to ensure a hassle free return and exchange policy because this will go a long way in building a bond of trust with the customers. To minimize product damages, the logistics providers should use good packing materials and give 'handle with care' tags for delicate items. Here the role of the customer support team also comes into play. They have to be courteous and understand the need of the customer who feels that the product was not up to his expectations.

\section{Conclusion:-}

Retailers today are employing numerous ways to communicate with the customers like emails, newsletters, social media, advertisements, text messages and calls. With these mediums they are able to touch base with their customers and inform them about the status of their order and other services. At the same time, the eCommerce players realize that the person who delivers the product is the face of the company for the customer. The behaviour of the delivery person is a crucial factor to build a rapport with the customer. It is important to keep track of the delivery personnel who can easily deviate from the company rules and give untimely delivery of products. The delivery men should not be overburdened also as their ill-mood can affect the way they communicate with the customer. Thus, retailers should partner with those logistics firms which are professional in their approach. 
The main role of logistics is to provide timely and efficient delivery of products so that the customer is sat isfied and becomes your repeat customer, and also earns you more customers. Today, the online shoppers have the powerful tool of social media in their hands. They simply have to post on facebook or tweet about their experience, and this can make or break a company's image. In today's competitive market conditions, retailers have to put in the best efforts to exceed customer satisfaction. Some of the largest e-retailers have implemented same-day delivery to woo customers who can't or won't wait for even next-day service. Some retailers offer free or low cost shipping for many products (after a particular price range). An online consumer is looking for attractive pricing and hassle-free delivery of products. An exceptional product delivery experience is critical in not just winning but retaining clients. So, it is in the best interest of the eCommerce players to entail professional logistics services which would result in faster growth, success and dynamism for the company. 